\title{
Neurovascular Pedicles of the Tibialis Anterior Muscle in Children
}

\author{
Pedículos Neurovasculares del Músculo Tibial Anterior en Niños
}

Jesus, R. C.; Lopes, M. C. H.; Ruiz, C. R.; Wafae, G. C. \& Wafae, N.

JESUS, R. C.; LOPES, M. C. H.; RUIZ, C. R.; WAFAE, G. C. \& WAFAE, N. Neurovascular pedicles of the tibialis anterior muscle in children. Int. J. Morphol., 26(2):313-316, 2008.

SUMMARY: The importance of the tibialis anterior muscle in infantile orthopedic transposition surgeries, as in myelomeningoceles, it bases this research about the neurovascular pedicles of the tibialis anterior muscle. The study was conducted on 34 legs of human cadavers that were one year old or younger at the time of death. It was observed that the tibialis anterior muscle most frequently presented from 7 to 10 arterial branches (52.4\%). In $97.1 \%$ of cases these branches were derived from the anterior tibial artery. In one case the anterior tibial artery was missing and the muscle was supplied by the fibular artery. Thirty-nine and seven tenths percent of arterial branches entered the superior third of the muscle; the middle third received $40.1 \%$ of the branches and the inferior third received $20.2 \%$ of the branches. The deep fibular nerve exclusively supplied the innervation, which in $91.2 \%$ of cases, gave off from 2 to 4 branches to the muscle, mainly to the superior (46.2\%) and middle third (43.0\%). Most frequently, there were two neurovascular pedicles supplying the superior third and one supplying the middle third.

KEY WORDS: Vascularization; Tibial anterior artery; Children anatomy.

\section{INTRODUCTION}

Children with lumbar myelomeningocele frequently present with foot deformities, especially those of the calcaneal type (Janda et al., 1984; Georgiadis \& Aronson, 1990; Fernández-Feliberti et al., 1992). Varus deformity of the foot secondary to spastic palsy are also mentioned (Vogt, 1998). In such cases, successful outcomes have been reported (Turner \& Cooper, 1971; Janda et al.; Bliss \& Menelaus, 1986; Georgiadis \& Aronson; Fernández-Feliberti et al.; Vogt) where the tibialis anterior muscle is surgically transposed by passing it posteriorly through the interosseous membrane and attaching it to the calcaneus.

A detailed knowledge of the blood supply and innervation of the tibialis anterior muscle is necessary for successful surgical results. The purpose of this study was to describe the neurovascular supply of the tibialis anterior muscle in children, since most of these surgeries are performed in children, with the hope that it will increase the success of this transposition surgery, not only in myelomeningocele but in all cases where it is recommended.

\section{MATERIAL AND METHOD}

We studied 34 formalin-fixed (10\%) legs of both sides of male and female cadavers of one year old or younger, obtained from the Anatomy Laboratory of the Morphology Department. For a better view of arterial branches, latex neoprene was injected into the descending thoracic aorta. Dissection began with a longitudinal incision on the middle anterior region of the leg, including skin and subcutaneous tissue. The tibialis anterior muscle was then exposed from its origin to its insertion and the vessels and nerves supplying it were identified and dissected. The origin, number and penetration level of the arteries and nerves was recorded.

\section{RESULTS}

The number of arterial branches supplying the tibialis anterior muscle most frequently $(61.7 \%)$ varied from 7 (8.8\%), $8(14.7 \%), 9(14.7 \%), 10(14.7 \%)$ to $11(8.8 \%)$ (Table I). In most cases, these branches originated from the ante- 
rior tibial artery (97.1\%); in one specimen (2.9\%) one branch originated from the fibular artery (Table I).

Table I. Number of the arterial branches supplying the tibialis anterior muscle.

\begin{tabular}{ccc}
\hline Branches & Total & \% \\
\hline $\mathbf{6}$ or less & 5 & 14.7 \\
$\mathbf{7}$ & 3 & 8.8 \\
$\mathbf{8}$ & 5 & 14.7 \\
$\mathbf{9}$ & 5 & 14.7 \\
$\mathbf{1 0}$ & 5 & 14.7 \\
$\mathbf{1 1}$ & 3 & 8.8 \\
$\mathbf{1 2}$ or more & 8 & 23.6 \\
Total & 34 & 100.0 \\
\hline
\end{tabular}

All branches origining from the anterior tibial artery coursed directly and exclusively to the tibialis anterior muscle. To determine the level at which the branch penetrated the muscle, we divided the length of the muscle into thirds. Thirty nine and eight tenths percent of the branches entered the superior third (Fig.1), $40.1 \%$ the middle third (Fig.2) and 20.2\% the inferior third. The inferior third includes the tendon, which in $70.6 \%$ of cases, received one $(79.2 \%)$ or two $(20.8 \%)$ branches.

The analysis of each specimen showed a 79.4\% incidence of branches in all three thirds (superior, middle and inferior) of the muscle, a $14.7 \%$ incidence in two thirds (superior and middle $-11.8 \%$; middle and inferior $-2.9 \%$ ) and a $5.9 \%$ incidence in the superior third only. In all cases the arterial branches penetrated the muscle on its surface.

In all cases innervation of the tibialis anterior muscle was from the deep fibular nerve (Fig.3), which most frequently gave off two (35.3\%), three $(41.2 \%)$ or four (14.7\%) branches to the muscle, as observed in $91.2 \%$ of the legs. These branches were accompanied by branches from the anterior tibial artery and veins, forming neurovascular

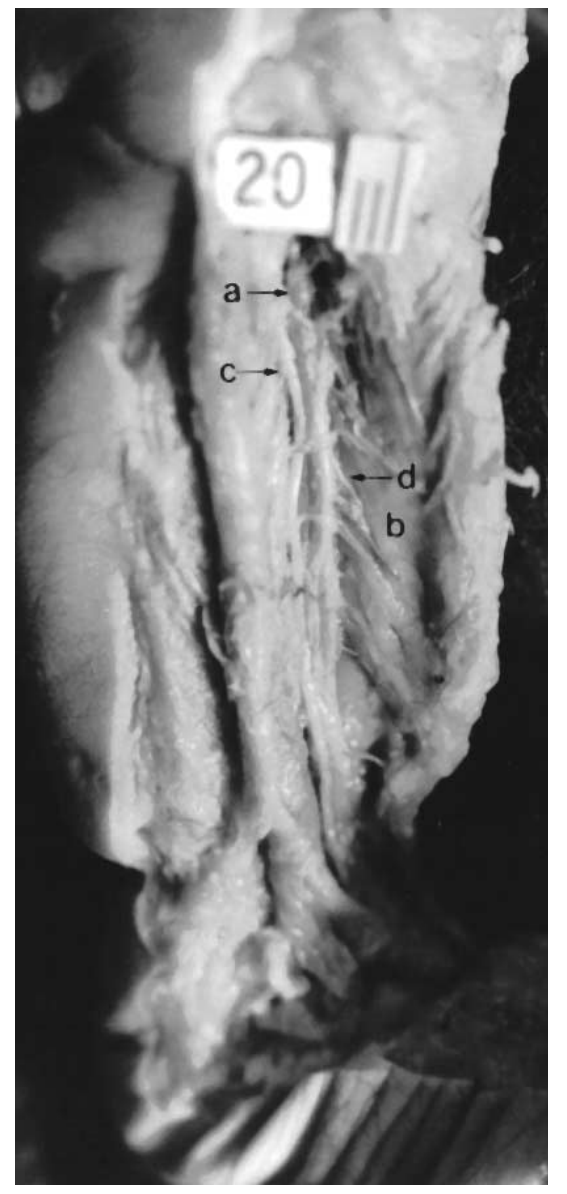

Fig. 1. Tibialis anterior muscle (b) demonstrating the anterior tibial artery (a), deep fibular nerve (c) and a neurovascular pedicle (d) supplying the superior third.

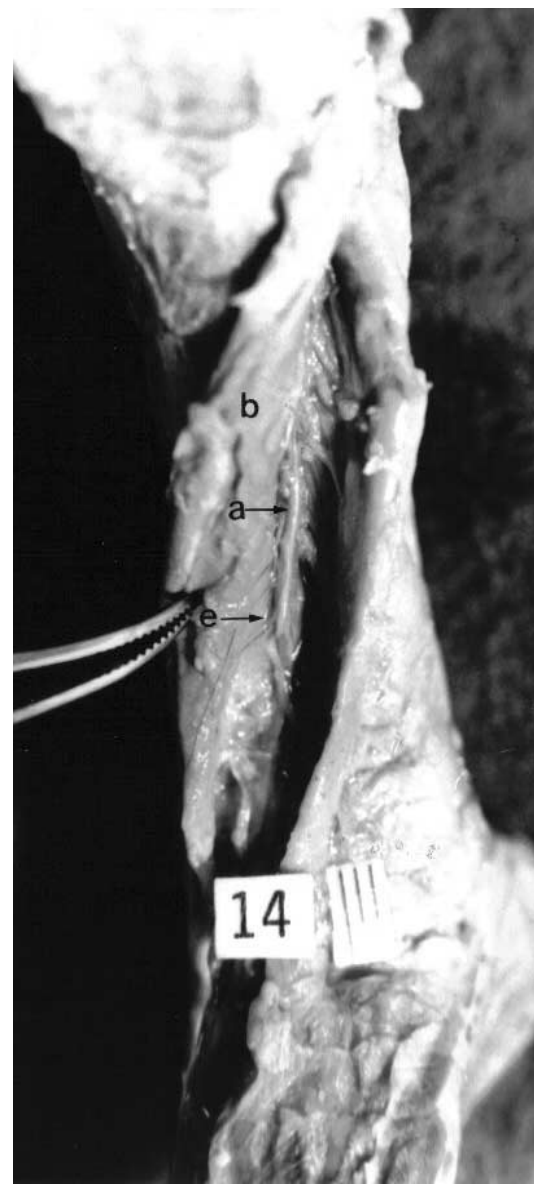

Fig. 2. Anterior tibial artery (a), tibialis anterior muscle (b), arterial branches (e) from the anterior tibial artery to the middle third of the tibialis anterior muscle.

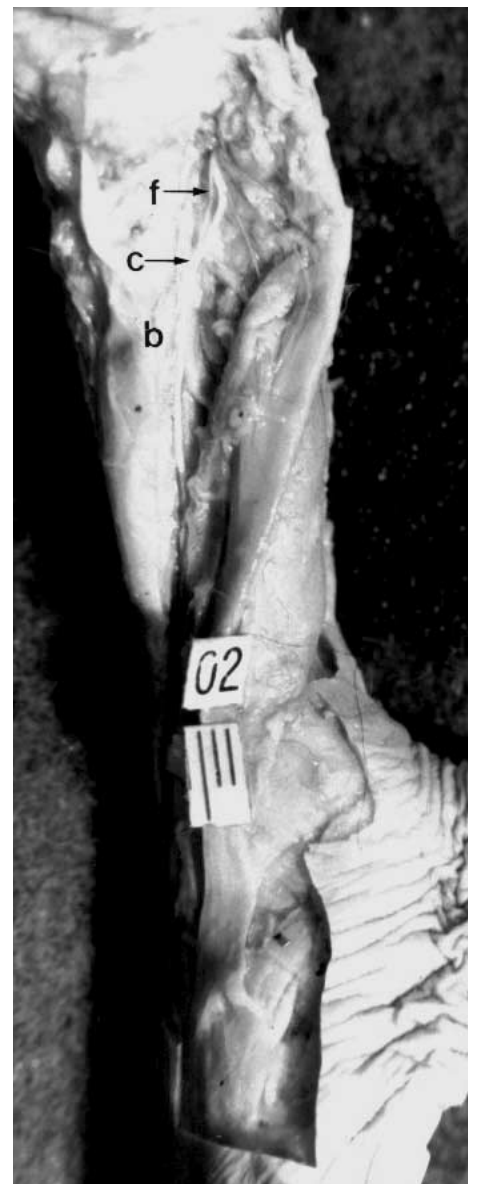

Fig. 3: Tibialis anterior muscle (b), deep fibular nerve (c) and deep fibular nerve branches (f) to the superior third of the tibialis anterior muscle. 
pedicles. We identified the level of penetration of the nerve branches, as we did for the artery, by dividing the muscle into thirds, and observed that in $46.2 \%$ of the cases the branches entered on the superior third, $43.0 \%$ the middle third and $10.8 \%$ the inferior third. The nerve branches always entered the posterior side of the muscle.

\section{DISCUSSION}

The described surgical technique of tibialis anterior muscle transposition surgery for the treatment of myelomeningocele and other neuromuscular disorders, in children, suggests a need for a better knowledge of the blood supply and innervation of this muscle in children. Our results provide helpful information regarding the most frequent location of the neurovascular pedicles supplying the anterior tibialis muscle. On the muscle's superior third we observed the presence of three branches from the anterior tibial artery accompanied by two branches from the deep fibular nerve; on the middle third, we most frequently observed four arterial branches with only one accompanied by a nervous branch; and on the inferior third, including the tendon, we most frequently found just one arterial branch. Therefore, three complete neurovascular pedicles were most commonly identified, being two on the superior third and one on the middle third. In just one case, an inferior third arterial branch was derived from the fibular artery, which in that specimen also gave origin to the dorsal artery of the foot. In this study our conclusions had been the following ones:

In children, the tibialis anterior muscle is almost exclusively perfused through the anterior tibial artery (97.1\%); although arterial branches varied in number, there were most frequently, from 7 to 10 branches (52.4\%).

The location of branches on the longitudinal axis of the muscle showed a prevailing disposition to the superior and middle thirds ( $39.7 \%$ and $40.1 \%$, respectively), but most frequently there are branches to all three thirds $(79.4 \%)$, including the tendon (70.6\%). The innervation of the tibialis anterior muscle is exclusively by the deep fibular nerve (100.0\%), which sends from two to four nervous branches to the muscle $(91.2 \%)$. The deep fibular nerve branches are most frequently located on the superior and middle thirds of the muscle (46.2\% and $43.0 \%$, respectively). Arterial and nervous branches penetrate the posterior surface of the tibialis anterior muscle $(100.0 \%)$.

Apart from some variations, most frequently the neurovascular pedicle pattern observed were two pedicles to the superior and one pedicle to the middle third of the tibialis anterior muscle.

JESUS, R. C.; LOPES, M. C. H.; RUIZ, C. R.; WAFAE, G. C. \& WAFAE, N. Pedículos neurovasculares del músculo tibial anterior en niños. Int. J. Morphol., 26(2):313-316, 2008.

RESUMEN: La importancia del músculo tibial anterior en cirugías de transposición ortopédica en niños, así como en casos de mielomeningocele, fundamenta su estudio respecto a sus pedículos neurovasculares. El estudio se realizó en 34 miembros inferiores de cadáveres de niños de un año o menos de edad. Se observó que el músculo tibial anterior presentaba con frecuencia 7 a 10 ramas arteriales $(52,4 \%)$. En 97,1\% de los casos estos ramos eran derivados de la arteria tibial anterior. En dos casos, la arteria tibial anterior estaba ausente y el músculo suplió su irrigación con la arteria fibular. En relación a la entrada de las ramas, 39,7\% lo hacen en el tercio superior del músculo. El tercio medio recibe $40,1 \%$ de las ramas y el tercio inferior recibe $20,2 \%$ de ellas. El nervio fibular profundo es la fuente principal de inervación, en 91,2\% de los casos provee 2 a 4 ramos para el músculo, de ellos el 46,2\% termina en el tercio superior y el $43 \%$ en el tercio medio. Con mayor frecuencia, existen dos pedículos neurovasculares supliendo el tercio superior y uno supliendo el tercio medio del músculo tibial anterior.

PALABRAS CLAVE: Vascularización; Arteria tibial anterior; Anatomía del niño.

\section{REFERENCES}

Bliss, D. G. \& Menelaus, M. B. The results of transfer of the tibialis anterior to the heel in patients who have a myelomeningocele. J. Bone Joint. Surg. Am., 68(8):1258$64,1986$.

Fernández-Feliberti, R.; Fernández, S. A.; Colón, C.; Ramírez, N.; Alegría, M. \& Cintrón, K. Transfer of the tibialis anterior for calcaneus deformity in myelodysplasia. J. Bone Joint. Surg. Am., 74(7):103841, 1992.

Georgiadis, G. M. \& Aronson, D. D. Posterior transfer of the anterior tibial tendon in children who have a myelomeningocele. J. Bone Joint. Surg. Am., 72(3):3928, 1990 . 
JESUS, R. C.; LOPES, M. C. H.; RUIZ, C. R.; WAFAE, G. C. \& WAFAE, N. Neurovascular pedicles of the tibialis anterior muscle in children. Int. J. Morphol., 26(2):313-316, 2008.

Janda, J. P.; Skinner, S. R. \& Barto, P. S. Posterior transfer of tibialis anterior in low-level myelodisplasia. Devel. Med. Child. Neurol. 26(1):100-3,1984.

Turner, J. W. \& Cooper, R. R. Posterior transposition of tibialis anterior through the interosseous membrane. Clin. Orthop. Relat. Res., 79:71-4, 1971.

Vogt, J. C. Split anterior tibial transfer for spastic equinovarus foot deformity: retrospective study of 73 operated feet. J. Foott Ankle Surg., 37(1):2-7, 1998.
Correspondence to:

Cristiane Regina Ruiz

Rua Roberto Koch, 34 - Ipiranga

Cep: 04221-060

São Paulo

BRAZIL

Phone: 55 (11) 65911264

Email: crisruiz@scamilo.edu.br

Received: 08-10-2007

Accepted: 18-03-2008 